\title{
Economic and environmental optimization of waste treatment
}

\author{
Münster, Marie; Ravn, Hans; Hedegaard, Karsten; Juul, Nina; Söderman, M. Ljunggren
}

Published in:

Waste Management

Link to article, DOI:

10.1016/j.wasman.2014.12.005

Publication date:

2015

Document Version

Peer reviewed version

Link back to DTU Orbit

Citation (APA):

Münster, M., Ravn, H., Hedegaard, K., Juul, N., \& Söderman, M. L. (2015). Economic and environmental optimization of waste treatment. Waste Management, 38, 486-495.

https://doi.org/10.1016/j.wasman.2014.12.005

\section{General rights}

Copyright and moral rights for the publications made accessible in the public portal are retained by the authors and/or other copyright owners and it is a condition of accessing publications that users recognise and abide by the legal requirements associated with these rights.

- Users may download and print one copy of any publication from the public portal for the purpose of private study or research.

- You may not further distribute the material or use it for any profit-making activity or commercial gain

- You may freely distribute the URL identifying the publication in the public portal 
ECONOMIC AND ENVIRONMENTAL OPTIMIZATION OF WASTE TREATMENT

\author{
M. MÜNSTER*, H. RAVN**, K. HEDEGAARD*, N. JUUL*, M. LJUNGGREN \\ SÖDERMAN***,****
}

*System Analysis Department, DTU Management Engineering, Technical University of

Denmark, Frederiksborgvej 399, 4000 Roskilde, Denmark

** RAM-løse edb, Ablevangen 55, 2765 Smørum, Denmark

*** IVL Swedish Environmental Research Institute, Box 53021, SE-40014 Gothenburg,

Sweden

**** Chalmers University of Technology, SE-412 96 Gothenburg, Sweden

SUMMARY: This article presents the new systems engineering optimization model, OptiWaste, which incorporates a life cycle assessment (LCA) methodology and captures important characteristics of waste management systems. As part of the optimization, the model identifies the most attractive waste management options. The model renders it possible to apply different optimization objectives such as minimizing costs or greenhouse gas emissions or to prioritize several objectives given different weights. A simple illustrative case is analysed, covering alternative treatments of one tonne of residual household waste: incineration of the full amount or sorting out organic waste for biogas production for either combined heat and power generation or as fuel in vehicles. The case study illustrates that the optimal solution depends on the objective and assumptions regarding the background system illustrated with different assumptions regarding displaced electricity production. The article shows that it is feasible to combine LCA methodology with optimization. Furthermore, it highlights the need for including the integrated waste and energy system into the model.

\title{
1. INTRODUCTION
}

The framework around management of waste and use of waste for energy is changing. The waste sector faces increased privatization, a growing international market and ambitious goals for increased material recycling. The EU member states are obliged to ensure recycling of minimum $50 \%$ of the municipal waste and 70\% of the construction waste by 2020 (European Parliament \& Council 2008). 
Meanwhile, the energy sector faces increased demand for renewable energy, including organic waste. Furthermore, there is an increased demand for flexibility and storage capacity in the energy system, due to increased production from fluctuating energy sources such as wind and solar power. EU has a target of achieving 20\% renewable energy by 2020. National Renewable Energy Plans from the EU countries show that the renewable share of electricity is expected to constitute $31 \%$ in 2020, of which wind power is expected to constitute $41 \%$ amounting up to $13 \%$ of total electricity consumption (Beurskens \& Hekkenberg 2011). In Denmark the share of wind power has already reached 28\% of the electricity consumption (Danish Energy Agency 2012) and the political goal is to reach 50\% by 2020 (Danish Ministry of Climate Energy and Building 2012).

In order to take the changed framework into account, it is necessary to develop new decision support tools for waste companies and national authorities. This way, they can avoid suboptimal environmental solutions. In the future, we may see an increased competition between using waste as an energy resource and as a source of recycled raw-materials. The competition is somewhat regulated by legislation within the sectors at a given time. It is, however, still interesting to explore what is feasible today and in the longer run, both from an economic, environmental, and societal perspective. In order to understand which types of waste will be available for each of these purposes, it is necessary to consider both the waste management sector and the energy sector. It will, thereby, be possible to answer questions such as: "What is the economically most feasible treatment of waste?", "Which type of sorting, recycling and energy conversion should we choose from an economical or environmental perspective?" and "What are the costs of extensive recycling policies?"

Currently, economic (as well as environmental analyses) of waste and energy systems are poorly linked (Juul et al. 2013; Münster 2009). Waste management solutions - including waste-to-energy (WtE) solutions - have so far primarily been analysed using life cycle assessments (LCA) with a focus on the environmental impact of the different waste management solutions, from the generation to the disposal of waste. Cost-benefit analysis (Dijkgraaf \& Vollebergh 2004; Eshet et al. 2005; Moutavtchi et al. 2008; Tietze-Stockinger et al. 2004), multi-criteria decision analysis (El Hanandeh \& El-Zein 2009; Longden et al. 2007; Morrissey \& Browne 2004; Shmelev \& Powell 2006) and various other tools, e.g., energy balance analysis (Dornburg \& Faaij 2006; Luoranen \& Horttanainen 2007; Murphy \& McKeogh 2004), have also been applied, albeit to a lesser degree. Alternatives may also be analysed with the use of optimization models, but normally not taking the energy sector into account (Broitman et al. 2012; Juul et al. 2013; Kan et al. 2010).

A number of reviews have been made of the long list of LCAs conducted of waste treatment options (e.g. Astrup et al. 2014; Bernstad \& La Cour Jansen 2012; Finnveden et al. 2007; Laurent et al. 2014; Morris et al. 2013; Sundberg et al. 2004; Villanueva \& Wenzel 2007; Winkler \& Bilitewski 2007). The reviews support the waste hierarchy applied in the EU (European Parliament \& Council 2008), at least the upper part: waste prevention is pointed out as the most preferable optionNumerous exceptions do, however, exist in the lower parts of the hierarchy (recycling, recovery and landfilling). Several reviewers conclude that there is no agreement in conclusions between the reviewed LCA studies. Laurent et al (2014) claim that "the strong dependence [...] on local conditions [...] prevents meaningful generalisation of the LCA results as [...] in the waste hierarchy” . Different factors which have a great significance on the conclusions were identified: assumptions on affected substitutions of energy and material were among these in several reviews.

Analyses which take into account the dynamic nature of the energy systems and the flexibility requirements, are not currently undertaken, as shown in studies reviewing existing models for waste management (Finnveden et al. 2006; Juul et al. 2013). The significance of taking dynamic effects and flexibility requirements into account has been shown for energy systems with a high degree of fluctuating power sources and combined heat and power production (CHP), which require a high 
degree of system flexibility. In (Münster \& Meibom 2010) it is shown, that when implementing changes in treatment of waste in this type of energy systems, not only production technologies, but also storage and transmission technologies are affected by the changes.

On the other hand, energy system analysis tools only have rudimentary representation of waste technologies and no possibility of prioritizing between energy and material recycling options (Münster \& Meibom 2010; Münster 2009).

Therefore, it is necessary to develop decision support tools which target both the demands of waste companies as well as the demands of national waste and energy authorities. This facilitates better planning for the energy and waste sectors.

Waste management LCAs typically focus on comparing two management alternatives during all the phases from waste generation to final disposal. On the other hand, energy systems analysis (ESA) focuses on one step of the life cycle (energy recovery), with a simulation of all interacting energy technologies. This is illustrated in Figure 1 in a simplified manner, with one WtE technology being in common between the waste LCA and the ESA.

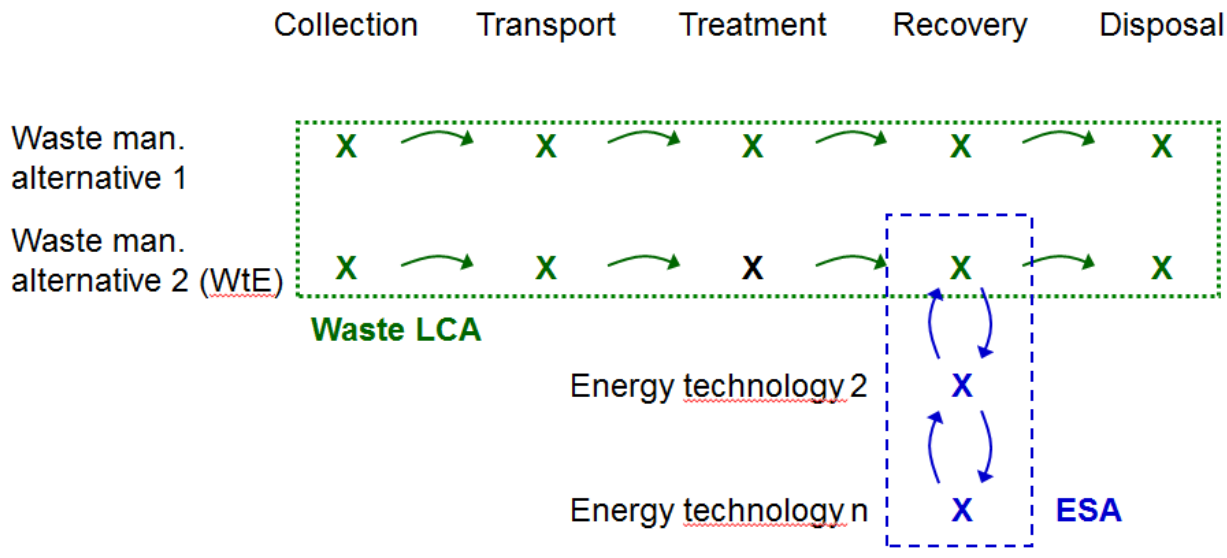

Figure 1. System boundaries of energy system analysis (ESA) and waste management life cycle assessment (LCA).

The system boundary applied in waste management LCAs intends to cover all relevant induced and avoided processes that occur as a consequence of the given waste treatment path. In terms of energy, this includes all relevant energy consumptions throughout the life cycle, including e.g. energy use for fuel extraction, fuel and waste transport and energy use and displacements resulting from the given waste treatment path. In contrast, ESA typically only cover the processes from the conversion of fuels, such as waste, to electricity and heat and subsequent transmission to the end users. Both LCA and ESA cover energy displacements resulting from waste based energy production; however applying different approaches, as described.

The results of ESAs can be used directly to prioritize between technologies according to an energy system perspective focusing on, e.g. costs, fuel efficiency, $\mathrm{CO}_{2}$ emissions from energy production, or renewable energy shares. Results of ESAs, e.g. in the form of marginal electricity and heat generation, can also be used as input data in waste management LCAs among others. Furthermore, ESA can contribute with results to other types of analyses focusing more on economy or societal effects, such as cost-benefit analysis or multi-criteria decision analysis (Morrissey \& Browne 2004).

In this article, the LCA and the ESA methodologies are combined. As such, a life cycle perspective is applied on waste management while integrating the cost minimization approach often applied in 
ESA. The tool, thus, makes it possible to optimize either from an economic or an environmental perspective with focus on minimizing greenhouse gas (GHG) emissions. The tool will later be developed to include a full representation of the energy system including a geographical and temporal dimension.

The new cost-optimization tool, OptiWaste, is being developed to optimize the use of waste on a national level considering both the waste management sector and the energy sector. The tool is built up around the same principles as the energy system analysis tool, Balmorel (Münster \& Meibom 2011; Ravn et al. 2001), but with detailed representation of the waste sector. The OptiWaste tool is a linear programming model, which minimizes socio-economic costs or emissions of waste treatment. The model focuses on costs, efficiencies and emissions related to waste treatment and energy production versus the income from recycled materials, or energy (in the form of heat, electricity or biofuels). The work builds on the Swedish experiences of developing optimization models for waste management planning such as NatWaste and MIMES/Waste (Ljunggren Söderman 2000). The OptiWaste model is being developed as part of the TOPWaste project (www.topwaste.dk) supported by the Danish Strategic Research Council. The source code for the model will be made readily available at the termination of the project.

\section{METHODOLOGY}

This section sketches LCA and ESA in a common formulation as optimization problems, an approach which is applied in the OptiWaste model. By combining the two perspectives into one model, aspects from both of these methodologies can be represented and balanced. When expressed as linear programming (LP) problems, LCA and ESA can commonly be formulated as:

$$
\begin{aligned}
& \max \mathrm{Z}=c^{\prime} x \\
& A x \leq b \\
& x \geq 0
\end{aligned}
$$

Here, c and b are column vectors of coefficients (input data), A is a matrix of coefficients, $\mathrm{x}$ is column a vector of variables and ' denotes transpose. The first line is the objective function which maximizes the value $Z$. This is done by choosing the optimal value of the $x$ vector subject to the equations and inequalities in the second and third lines. The model in Eq. (1) is widely used in ESA, e.g. in Balmorel (Ravn et al. 2001). In such an application, the inequalities may represent e.g. capacity constraints on production, storage and transmission units, fuel use restrictions, and emission limits on $\mathrm{CO}_{2}$. The LCA optimization problem has no inequalities $(\leq)$, hence $\mathrm{Ax}=\mathrm{b}$ in (1) a single equation (i.e., one row) will then specify relations between, e.g. the flow of waste entering a sorting process and the various fractions leaving the sorting process. Other equations can specify emissions, and energy and resource consumption associated with the processes. This reflects that in LCA, a number of discrete fixed alternatives are typically simulated and compared with the goal of identifying the most attractive option among them. Such comparative analyses can for instance cover energy recovery versus recycling of a given waste fraction. As such, the best solutions are not identified as part of an optimization, but based on the interpretation of the simulated results of the LCA.

As outlined above, LCAs can however be formulated on the same form as linear optimization problems. Thus, when integrating the life cycle impacts of several possible alternatives into a single optimization model, the optimal alternative or combination of alternatives can be identified through optimization. This modelling approach is fully compatible with the approach often used for ESA and, 
hence, qualified for a future integration into an energy system model.

One of the key differences between LCA and ESA is the many qualities of flows that have to be handled in LCA. The reason is that for each process a waste stream undergoes - such as sorting, bundling, transportation, incineration, recycling and other - it may change its quality. Here, quality is understood in a broad sense and may cover, e.g. heating value, content of embedded fossil carbon, or contaminants. The aspect of changing qualities is in contrast to how flows of electricity, heat, and fuel are traditionally handled in most ESAs. These flows do not change quality.

In order to capture the central role of flow qualities within waste management systems, the OptiWaste model is formulated in the form of a network of processes and flows. The processes represent, e.g. sorting or incineration as mentioned above, while the flows represent streams of waste fractions. Flows are usually directed in the sense that any flow has a 'from' process and a 'to' process. Network formulations are used for many other purposes than waste handling, and, thus, there are solid experience and theory behind e.g. (Bazaraa et al. 2010).

Another challenge in the combined handling of waste and energy systems is the different need for modelling time. In ESA representation of time is essential because energy conversion plants change their production over time, in daily, weekly and seasonal patterns to meet the shifting energy demand. In turn, this change is associated with changes in marginal production units with consequences for marginal fuel consumption, emission and costs. Also longer time perspectives (over several years) are relevant, in relation to capacity investments etc. In LCA the time differentiation or dynamics within the years is usually ignored, while aspects related to the longer time frame (e.g. 100 years) may be central.

A third challenge is how to account for geographical conditions. Geography is relevant for transportation of waste (LCA), district heating areas or transmission of electricity between regions and countries (ESA), and legislation that mostly is defined on a national level.

In this article, focus is on the challenge of modelling the many qualities of flows.

\section{MODEL DESCRIPTION}

This section provides a formal description of the network model applied in OptiWaste. The model is implemented in GAMS, an algebraic modelling system that is in widespread use for applications such as ESA, cf. e.g. (Ravn et al. 2001). The network model is a special case of the LP model (1).

The emphasis is on the key equations, including the objective function, for the waste network flow part of the model. Symbols are illustrated in Table 1. The description of the non-waste energy part of the model is omitted as this is more in line with well-known energy modelling principles, see e.g. (Ravn et al. 2001).

The model can optimize with regard to different objectives, e.g. minimizing total costs, as typically applied in ESA models, or minimizing either environmental impact potentials (e.g. climate change potential quantified in the form of $\mathrm{CO}_{2}$-equivalents) or resource consumptions, in line with the objectives applied in LCAs. This flexibility is implemented by including different types of indicators (e.g. costs or GHG emissions) in the objective function:

$$
Z=\sum_{(p, f) \mid\left(p \in P^{I d c} \text { and } f \in F^{I d c}\right)} P_{f}^{I d c} \cdot W_{f}^{I d c}
$$

By choice of weights $W^{I d c}$ (with the value 0 through 1 ), the relative importance of each indicator is specified, here represented as the net flow from $P^{I d c}$. Thereby, it is possible to optimize with regard to 
one or several indicators.

The key equations of the model are those that describe the balances of the flows entering and leaving a process. For waste management systems, these can, e.g. describe mass balances, i.e. that the sum of incoming mass equals the sum of outgoing mass. Other examples cover specification of cost or emissions associated with operating the process that a specific $P$ represents. Another type of relation concerns restrictions related to the topology, ensuring, e.g. that only specific flows may enter specific processes.

Table 1. Symbols used for the OptiWaste model description. Sets and parameters describe input data while the value of variables is identified as part of the optimization.

\begin{tabular}{lllll}
\hline Symbol & Type & Description & Indexes & Comment \\
\hline$P$ & Set & Set of Processes & - & - \\
\hline$P^{S}$ & Set & Set of Source Processes & $P$ & Subset of $P$ \\
\hline$P^{I}$ & Set & Set of Sink Processes & $P$ & Subset of $P$ \\
\hline$P^{B}$ & Set & Set of Buffer Processes & $P$ & Subset of $P$ \\
\hline$P^{I n t}$ & Set & Set of Interior processes & $P$ & Subset of $P$ \\
\hline$P^{W}$ & Set & Set of waste generation Processes & $P$ & Subset of $P$ \\
\hline$P^{I d c}$ & Set & Set of Processes for indicators & $P$ & Subset of $P$ \\
\hline$F$ & Set & All Flows & - & $F$ \\
\hline$F^{I d c}$ & Set & Indicator Flows & $F$ & Subset of $F$ \\
\hline$F^{W}$ & Set & Waste generation Flows & $P, P, F$ & $P, F, F$ \\
\hline$R^{P P F}$ & Set & Relation specifying Flow is from Process to Process & of $F$ \\
\hline$R^{P F F}$ & Parameter & Relation specifying Flows into and from Process & $F$ & $P$ \\
\hline$W^{\text {Idc }}$ & Parameter & Weight of given element in objective function & $P^{B}, F$ & Free \\
\hline$V^{\text {Idc }}$ & Variable & Indicator Flow & $P$ & Positive \\
\hline$Z$ & Variable & Objective function value & Free \\
\hline$V$ & Variable & Flow between two processes & Positive \\
\hline$V^{S}$ & Variable & Net Flow from Source Process & Positive \\
\hline$V^{I}$ & Variable & Net Flow from Sink Process & Negative \\
\hline$V^{B}$ & Variable & Net Flow from Buffer Process & $P$ \\
\hline
\end{tabular}

The set of Processes (P) are classified into four types: Source $\left(P^{S}\right)$, Sink $\left(P^{I}\right)$, Buffer $\left(P^{B}\right)$ and Interior $\left(P^{I n t}\right)$ Processes. Here, Source Processes are those that only have leaving Flows; e.g., the waste generation from household consumption may be represented as a Source Process if the origins of the consumed goods are not accounted for. Sink Processes have only entering Flows; e.g., landfill may be represented as a Sink Process, if the landfill is modelled as having no consequences. Thinking of Source and Sink Processes as "boundary" Processes with known sign of the net Flow from the Processes (positive for Source, negative for Sink Processes), also the Buffer Processes are "boundary" Processes, however, in contrast to Source and Sink Processes the sign of the net Flow from a Buffer Process is not known a priori. Finally, the set of Interior Processes consist of Processes that are neither Source nor Sink nor Buffer Processes.

Each variable listed in Table 1 is actually a vector (except $Z$ ). A specific element in such a vector is specified by sub-indices, e.g. $V p, p^{\prime}, f$ is the element in $V$ representing Flow $f$ from Process $p$ to Process $p^{\prime}$. Similar notational convention applies for parameters. 
Most Flows are positive (or zero), since they typically represent a physical entity. The exception is the net flow from Buffer Processes, $P^{B}$, which may be positive, zero, or negative. This is due to the use of Buffer Processes also for representing some net balances. For instance, a Buffer Process may represent an electricity hub that receives electricity generated by a waste incineration plant and delivers electricity to a waste sorting plant. Without further information it is not possible to know the sign of the net Flow from the Buffer Process. The Buffer Flow variable is therefore declared as free. The indicator Flow $V^{I d c}$ is also declared as a free variable.

The sets $P^{S}, P^{I}, P^{B}$, and $P^{I n t}$ are non-overlapping and together constitute set $P$. The relation between set $\mathrm{P}^{\mathrm{Idc}}$ of indicator nodes and the other subsets of $P$ is user specified. Typically, $P^{I d c}$ will be the set $P^{B}$ of buffer nodes but it may be a subset thereof.

The process balance equations are of four kinds, relative to elements of $P$ that are of type Source, Sink, Buffer or Interior, respectively.

For the Source Process, the equation is for any given Process $p \in P^{S}$ and any Flow $f \in F$ leaving $p$ and entering some other $p^{\prime}$. This equation is indexed over $(p, f)$. Thus,

$$
V_{p, f}^{S}=\sum_{p^{n} R_{p, p^{\prime}, f}^{P P F}} V_{p, p^{\prime}, f}, p \in P^{S}
$$

For the Sink Process, the equation is for any given Process $p \in P^{I}$ and any Flow $f \in F$ entering $\mathrm{p}$ coming from some other $p^{\prime}$. This equation is indexed over $(p, f)$. Thus,

$$
V_{p, f}^{I}=-\sum_{p^{\prime} \mid R_{p^{\prime}, p, f}^{P P}} V_{p^{\prime}, p, f}, p \in P^{I}
$$

For the Buffer Process, the equation is for any given Process $p \in P^{B}$ and any Flow entering $p$ coming from some other $p^{\prime}$. This equation is indexed over $(p, f)$. The sign convention is chosen such that if a Source or a Sink Process is reclassified as a Buffer Process the sign of the net Flow from the Process remains unchanged. Thus,

$$
V_{p, f}^{B}=\sum_{p^{\|} R_{p, p^{\prime}, f}^{P P F}} V_{p, p^{\prime}, f}-\sum_{p^{\|} R_{p^{\prime}, p, f}^{P P F}} V_{p^{\prime}, p, f}, p \in P^{B}
$$

For an Interior Process, the equation is more complicated. This equation is indexed over ( $\left.p, f, f^{\prime}\right)$. The relations between leaving and entering Flows are specified in parameter $\mathrm{R}^{\mathrm{PFF}}$. There are two main kinds of such relations, either fixed proportions of variable proportions. The latter kind is for handling two or more inflows of the same quality that are summarised, e.g. household waste from two cities that are handled at the same treatment facility. Likewise it is for handling one entering Flow that is split in two or more leaving flows of the same quality, e.g. for representing a choice between incineration and landfill. The following equation uses two sets PFFvso and PFFvsi are defined as subsets of tuples on $(P F F)$. PFFvso concerns the situation where a Flow entering an Interior Process is leaving the Process as two or more Flows (as specified in $R^{P P F}$ ). To ensure that double counting is avoided, all the leaving Flows except one (arbitrary) is made members of PFFvso. Similarly, for the case where two or more Flows entering an Interior Process are combined into one leaving Flow, all except one arbitrary are made members of PFFvsi. The equation then is specified for any given Process, $p \in P$, and any given Flow, $f \in F$, into $p$ and any given Flow, $f^{\prime} \in P$, leaving $p$, such that $\left(\mathrm{p}, \mathrm{f}, \mathrm{f}^{\prime}\right) \notin \mathrm{P}_{\mathrm{p}, \mathrm{f}, \mathrm{f}^{\prime}}^{\mathrm{PFFvs}}$ and $\left(\mathrm{p}, \mathrm{f}, \mathrm{f}^{\prime}\right) \notin$ $\mathrm{P}_{\mathrm{p}, \mathrm{f}, \mathrm{f}^{\prime}}^{\mathrm{PFFvi}}$. 


$$
\begin{aligned}
& \sum_{p_{1} \mid\left(R_{p_{1}, p, f}^{P P F} \text { and } p \notin P_{p, f, f^{\prime}}^{P F F v o} \text { and } p \notin P_{p, f, f^{\prime}}^{P F v v i}\right)} V_{p_{1}, p, f} \cdot R_{p, f, f^{\prime}}^{P F F} \\
& +\sum_{p^{\prime} \mid\left(R_{p^{\prime}, p, f}^{P P F} \text { and } p \in P_{p, f, f^{\prime}}^{P F F v i 2}\right)} V_{p^{\prime}, p, f} \\
& = \\
& \sum_{p_{1} \|\left(R_{p, p 1, f}^{P P F} \text { and } p \notin P_{p, f, f^{\prime}}^{P F F v i} \text { and } p \notin P_{p, f, f^{\prime}}^{P F F v o}\right)} V_{p, p_{1}, f^{\prime}} \\
& +\sum_{p^{\prime}\left(R_{p, p^{\prime}, f^{\prime}}^{P P{ }^{\prime}} \text { and } p \in P_{p, f, f^{\prime}}^{P F F v o 2}\right)} V_{p, p^{\prime}, f^{\prime}}
\end{aligned}
$$

In the equation the first terms on the left represent inflow that will go to outflow in fixed proportions (given by $R^{P F F}$ ). The second term on the left represents summation (in free proportions) of inflows that will go to a single outflow. The first term on the right represents a single outflow that will come from one or more inflows in fixed proportions. The last term on the right represents summation (in free proportions) of outflows from a single inflow.

Instances of any of the above three types of equations are generated only for those combinations of process and Flows that are relevant according to the input data. Thus, in particular there is no instance that involves combinations of Flows and Processes that are not linked through input data $R^{P P F}$.

In addition to the above equations the model admits formulation of inequalities. Such inequalities may represent upper or lower bounds on flows (e.g. capacity limits), or they may represent upper or lower bounds on the relative share of individual entering (leaving) flows that are summarised to a single leaving (entering) flow (e.g., upper limit on the share of low quality waste fuel in an incineration plant). Also more complex inequalities may be entered, however, as they will typically be case specific they will not be illustrated here as part of the general description.

It should be clear that the above equations are suited for representation of a fairly broad class of networks, and as the equations are linear, any such network may be represented as in (1). In particular, a waste handling systems as well as an energy system may be represented. Thus, the Processes may represent waste generation, collection, handling etc., as well as energy transformation plants, primal fuel acquisition, energy consumption etc. Likewise, Flows may represent flows of waste, energy, emission, money etc. And, essential in this context, waste and energy Processes and Flows may be represented in the same network in a homogenous ways.

With the above described model, it is possible to perform optimization of waste treatment and energy systems based on minimization of costs or environmental impacts as illustrated in the case described next.

\section{ILLUSTRATIVE CASE STUDY}

\subsection{Waste treatment alternatives}

The OptiWaste model functionality is illustrated by analysis of three waste treatment alternatives for treatment of 1 tonne of residual household waste, see Table 2 and Figures 2 to 4 . The residual household waste is a weighted average of Danish household waste mainly consisting of organic waste (50\%), paper and cardboard (20\% ) and plastic (10\%) (Petersen \& Domela 2003). The most important parameters for the waste treatment alternatives and the references applied are given in Table 3.

A short term marginal approach, where operation is optimised, is applied in the illustrative case - and hence only variable costs are included. Socio-economic costs are applied, i.e. excluding taxes, tariffs 
and subsidies, given in €-2009. Externalities, such as environmental damage costs, have, however, not been internalized in the costs. A near term perspective towards 2020 is applied. The environmental optimization is illustrated with focus on greenhouse gas emissions, applying a consequential LCA approach.

Table 2. Overview of the modelled treatment alternatives of 1 tonne residual household waste.

\begin{tabular}{ll}
\hline Name & Short description \\
\hline Incineration & $\begin{array}{l}\text { Incineration of the residual household waste at a waste } \\
\text { incineration combined heat and power (CHP) plant. }\end{array}$ \\
\hline Biogas_CHP & $\begin{array}{l}\text { Sorting out bio waste from the residual household waste for } \\
\text { production of biogas, which is then used for CHP generation. } \\
\text { The remaining household waste is incinerated (CHP). }\end{array}$ \\
\hline Biogas_Transport & $\begin{array}{l}\text { Sorting out bio waste from the residual household waste for } \\
\text { biogas production, which is then used as fuel in vehicles as } \\
\text { CBG. The remaining household waste is incinerated (CHP). }\end{array}$ \\
\hline
\end{tabular}

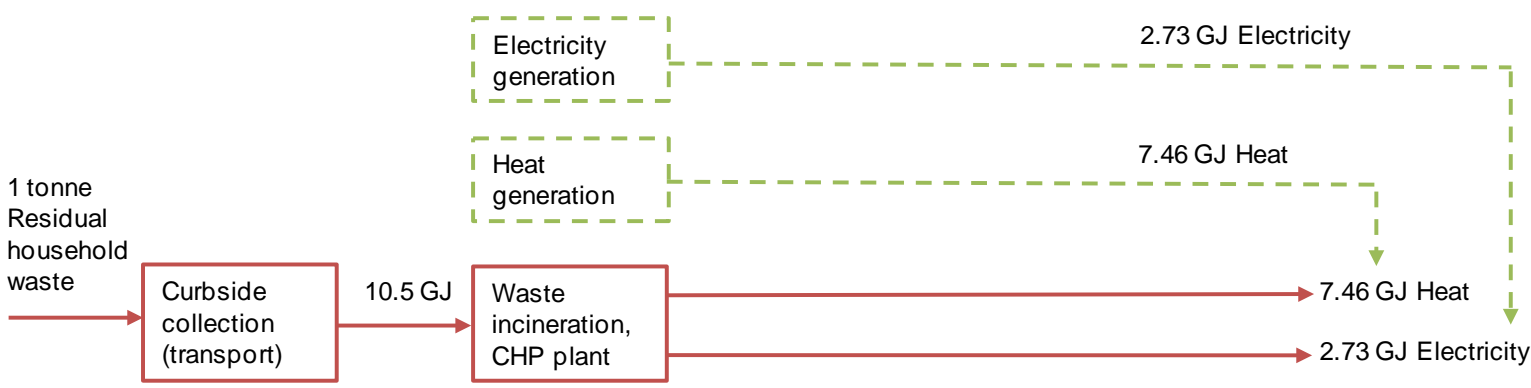

Figure. 2. Process flow diagram for the Incineration alternative. Induced processes/flows are indicated with red and avoided processes/flows with dashed green.(Danish Energy Agency 2011; Danish Energy Agency \& Energinet.dk 2012)

Figure 2 shows that in the Incineration alternative, 1 tonne of residual household waste is transported to a waste incineration CHP plant. The heat generation is relatively high due to a high heat efficiency of waste incineration plants (71\%), while the electricity efficiency is lower (26\%) (Danish Energy Agency \& Energinet.dk 2012). 
Table 3. Data applied in the illustrative case study.

\begin{tabular}{|c|c|c|c|c|}
\hline Process & Parameter & Unit & Value & Reference \\
\hline \multirow{2}{*}{$\begin{array}{l}\text { Waste incineration, CHP (with } \\
\text { flue gas condensation, vintage: } \\
\text { 2020) }\end{array}$} & $\begin{array}{l}\text { Electric } \\
\text { efficiency, net }\end{array}$ & $\%$ & 26 & $\begin{array}{l}\text { Danish Energy Agency \& Energinet.dk } \\
2012\end{array}$ \\
\hline & $\begin{array}{l}\text { Variable O\&M } \\
\text { costs }\end{array}$ & $€ / G J$ waste & 4.8 & $\begin{array}{l}\text { Danish Energy Agency \& Energinet.dk } \\
2012\end{array}$ \\
\hline \multirow{3}{*}{ Anaerobic digestion } & Biogas output & GJ biogas/tonne biowaste & 3.8 & Bernstad 2012 \\
\hline & $\begin{array}{l}\text { Heat } \\
\text { consumption }\end{array}$ & GJ heat/tonne biowaste & 0.81 & $\begin{array}{l}\text { Danish Energy Agency \& Energinet.dk } \\
2012\end{array}$ \\
\hline & Digestate output & $\begin{array}{l}\text { Tonne digestate/tonne } \\
\text { biowaste }\end{array}$ & 2.5 & Bernstad 2012 \\
\hline \multirow{2}{*}{ Biogas CHP (vintage: 2020) } & $\begin{array}{l}\text { Heat efficiency, } \\
\text { gross/net }^{\text {a,d }}\end{array}$ & $\%$ & $46 / 18 \%$ & $\begin{array}{l}\text { Danish Energy Agency \& Energinet.dk } \\
2012 .\end{array}$ \\
\hline & $\begin{array}{l}\text { Variable O\&M } \\
\text { costs }\end{array}$ & $€ / G J$ biogas & 11 & $\begin{array}{l}\text { Danish Energy Agency \& Energinet.dk } \\
2012\end{array}$ \\
\hline \multirow[t]{2}{*}{$\begin{array}{l}\text { Biogas upgrading and } \\
\text { compression }\end{array}$} & $\begin{array}{l}\text { Electricity } \\
\text { consumption }\end{array}$ & GJ electricity/GJ biogas & 0.045 & $\begin{array}{l}\text { Danish Energy Agency \& Energinet.dk } \\
2012\end{array}$ \\
\hline & Variable costs & $€ / G J$ biogas & 1.1 & $\begin{array}{l}\text { Danish Energy Agency \& Energinet.dk } \\
2012\end{array}$ \\
\hline CBG vehicle & $\begin{array}{l}\text { Vehicle } \\
\text { efficiency }\end{array}$ & $\mathrm{km} / \mathrm{GJ}$ biogas & 534 & Edwards et al 2011 \\
\hline \multirow[t]{2}{*}{$\begin{array}{l}\text { District heat generation, Danish } \\
\text { average, } 2020^{\mathrm{C}}\end{array}$} & $\begin{array}{l}\text { Socio-economic } \\
\text { price }\end{array}$ & $€ / G J$ electricity & 11 & Danish Energy Agency 2011 \\
\hline & GHG emissions & kg CO${ }_{2}$-eq/GJ electricity & 34 & Danish Energy Agency 2011 \\
\hline \multirow[t]{4}{*}{$\begin{array}{l}\text { Storage and spreading of } \\
\text { digestate on field }\end{array}$} & GHG emissions & $\begin{array}{l}\mathrm{kg} \mathrm{CO} \text {-eq/tonne } \\
\text { digestate }\end{array}$ & 101 & Hamelin 2013 \\
\hline & N content & kg N/kg digestate & 5.30 & Hamelin 2013 \\
\hline & P content & kg P/kg digestate & 0.84 & Hamelin 2013 \\
\hline & K content & $\mathrm{kg} \mathrm{K} / \mathrm{kg}$ digestate & 2.20 & Hamelin 2013 \\
\hline $\begin{array}{l}\text { Curbside collection of } \\
\text { household waste }\end{array}$ & $\begin{array}{l}\text { Variable O\&M } \\
\text { costs }\end{array}$ & $€ /$ tonne waste & 63 & Dall, 2013 \\
\hline
\end{tabular}

\footnotetext{
${ }^{\mathrm{a}}$ Lower heating values applied.

${ }^{\mathrm{b}}$ Net variable costs covering transport cost and benefit of odour reduction.

${ }^{\mathrm{c}}$ At plant, i.e. including grid losses.

${ }^{d}$ Net efficiency accounts for heat consumption in the prior anaerobic digestion process.
} 


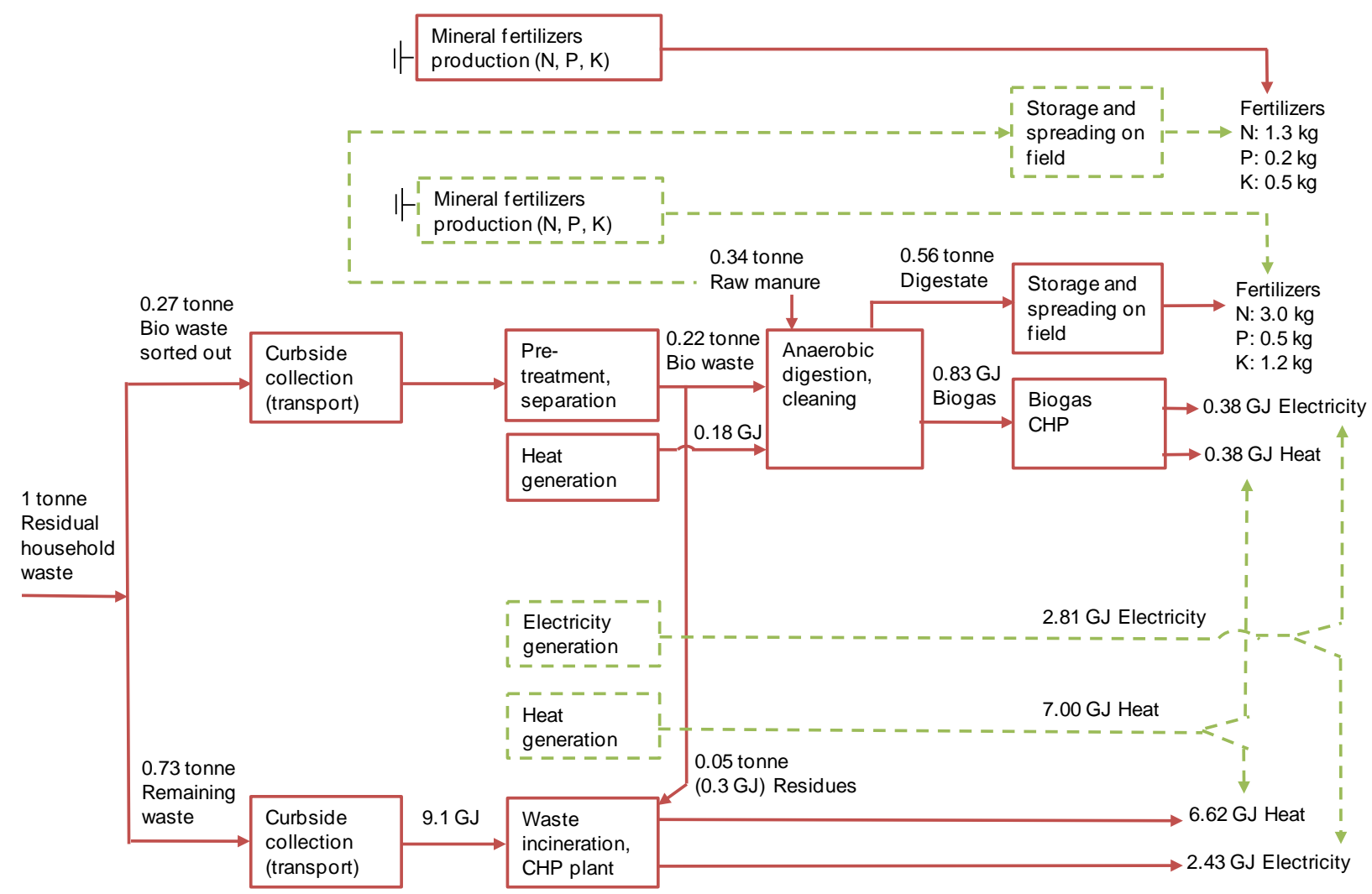

Figure 3. Process flow diagram for the Biogas_CHP alternative. Induced processes/flows are indicated with red and avoided processes/flows with dashed green. (Danish Energy Agency 2011; Danish Energy Agency \& Energinet.dk 2012; Hamelin 2013; Nielsen et al. 2002)

In the Biogas_CHP alternative, 0.27 tonne bio waste is sorted out from the residual household waste (see Figure 3). It is assumed that $50 \%$ of the bio waste content can be sorted out in the households on average. The remaining waste fraction of 0.73 tonne is sent to waste incineration. The bio waste is pretreated and separated where non-bio waste parts (mainly plastic bags) are removed and sent to waste incineration. The bio waste output from the pre-treatment/separation is then co-digested together with raw manure resulting in production of biogas. The biogas is used as fuel for CHP generation resulting in heat and power generation. The digestate is spread on fields as an organic fertilizer and assumed to displace production of mineral fertilizer products. The raw manure used in the co-digestion process is removed from its typical application as organic fertilizer on the field. Nevertheless, the nitrogen, N, phosphorous, $\mathrm{P}$, and Potassium, $\mathrm{K}$, content in the digestate is higher than in the raw manure, as shown in Figure 3, due to the addition of organic waste.

The electricity generation from the biogas CHP plant is relatively high due to a high electric efficiency (approx. 46 \%) (Danish Energy Agency \& Energinet.dk 2012). As a result the net electricity generation is slightly higher compared to the Incineration alternative (0.04 GJ higher when accounting for electricity consumption for processing of bio waste). On the other hand, the heat efficiency of the biogas CHP unit is lower than for a waste incineration plant (46\% compared to $71 \%$ for waste incineration) (Danish Energy Agency \& Energinet.dk 2012). Moreover, part of the residual household waste is used for soil improvement instead of energy recovery. Overall, the net heat generation is, 
therefore, lower in the Biogas_CHP alternative compared to in the Incineration alternative (around 0.64 GJ lower when also accounting for the heat consumed in the digestion process).

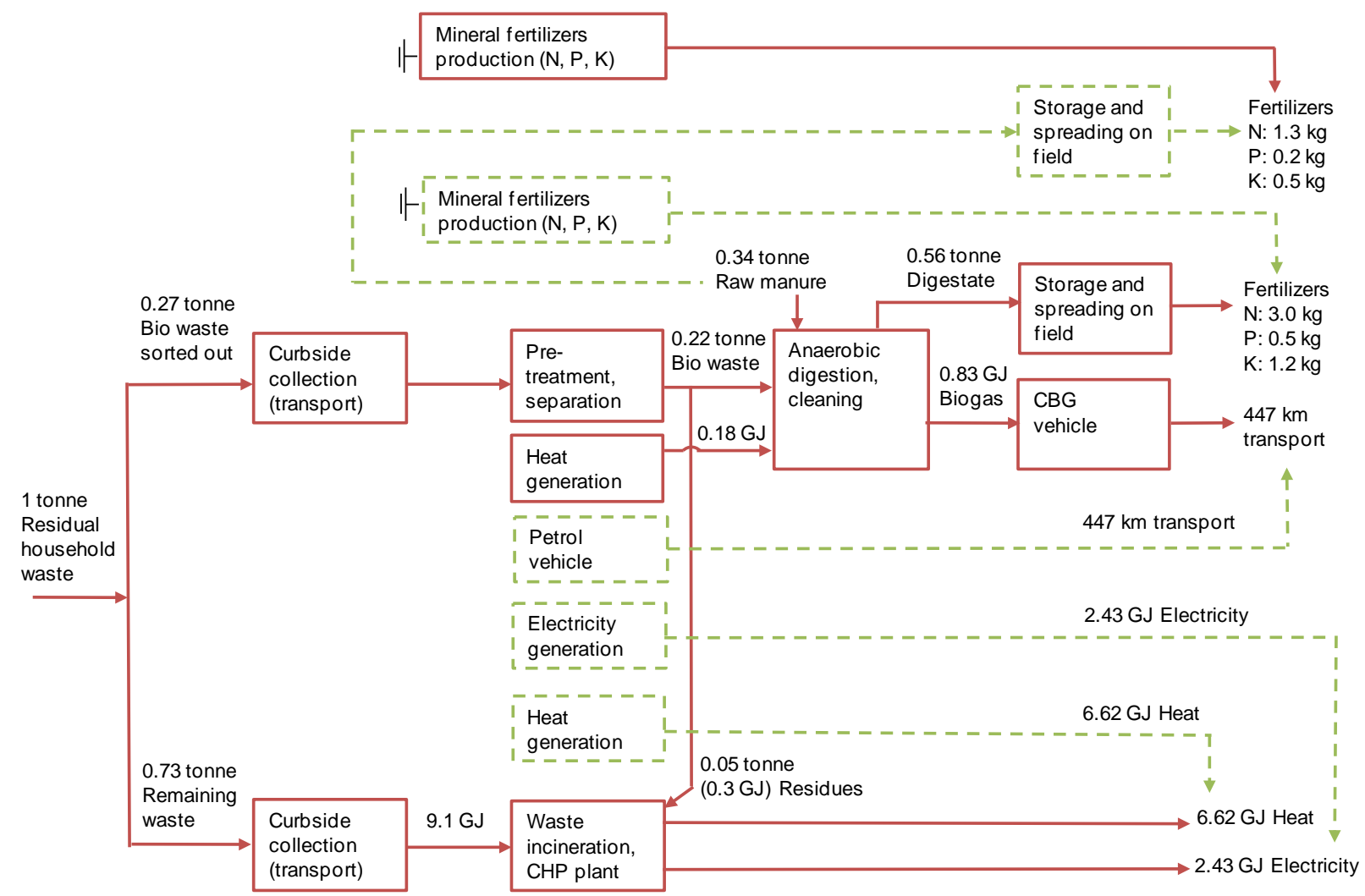

Figure 4. Process flow diagram for the Biogas_Transport alternative. Induced processes/flows are indicated with red and avoided processes/flows with dashed green. (Danish Energy Agency 2011; Danish Energy Agency \& Energinet.dk 2012; Edwards et al. 2011; Hamelin 2013; Nielsen et al. 2002). Energy consumption and costs for biogas upgrading and compression prior to use as fuel in vehicles is modelled (see Table 3) but is not visible on the flow diagram.

In the Biogas_Transport alternative, the biogas produced from the co-digestion of bio waste and manure is used as fuel in a vehicle. We are assuming this is in a vehicle dedicated for using compressed biogas as fuel (CBG) (see Figure 4). The vehicle fuel input of 0.83 GJ compressed biogas provides 447 $\mathrm{km}$ of transport, which is assumed to displace and equivalent amount of transport in a petrol fuelled vehicle (Edwards et al. 2011).

The optimal waste treatment path is identified endogenously as a result of the optimization. In this regard, the variables to be determined comprise the amount of bio waste sorted out for biogas production, and the amount of biogas utilized for CHP and fuel in vehicles, respectively.

\subsection{Optimization approach}

The three alternatives are formulated within a single model, which will choose the optimal alternative with regard to the objective function. This model has a Source Process which represents generation of 1 tonne of residual household waste. The Flow of waste from this Process goes to a second Process, 
where it is split in variable proportions between three leaving Flows. The leaving Flows from this second process are identical to the initial Flows of the three waste treatment alternatives described above. The freedom of choice of how large share of the residual household waste to send for which kind of treatment, is at the core of the optimization problem in this illustrative example. All other relations are in fixed relations, as described above.

The system is optimized with regard to two different objectives, in order to analyse the impact of different objectives and to illustrate the flexibility of the model:

- Minimizing total greenhouse gas (GHG) emissions $\left(\mathrm{CO}_{2}, \mathrm{CH}_{4}\right.$ and $\left.\mathrm{N}_{2} \mathrm{O}\right)$.

- Minimizing total operation costs.

In this analysis a comparison is made between costs and emissions of existing plants. If both operation and investment forms part of the optimization objective, and investment costs are included in the analysis, the results could be used to find optimal investment alternatives. Furthermore, including taxes, subsidies and tariffs would render results on feasible investments from a private economic perspective. Both aspects could be interesting to include in future studies.

In comparative environmental and economic assessments of waste-to-energy technologies, assumptions regarding the background system can be highly influential, e.g. which type of electricity and heat generation is assumed to be displaced by the waste-to-energy technologies. The displaced electricity generation depends on factors, such as the power system in question, electricity trade with neighbouring regions, the regulation properties of the waste-to-energy technology in question, and whether a short term marginal approach (excluding investments in new capacities) or a long term marginal approach (including investments in new capacities) is applied. These complexities can be captured by integrating the waste-to-energy technologies in energy system models, as will be done in future work. In this case study, different types of displaced electricity generation are assumed in order to illustrate its influence on the results (see Table 4). The displaced heat generation varies, e.g. with the district heating area. For simplicity, all the heat generated from the waste-to-energy technologies are assumed to displace average Danish district heating.

The different types of displaced electricity generation in Table 4 are based on (Danish Energy Agency 2011), where different approaches are given for assessing effects of increasing or reducing electricity demand in Denmark. The assumption of displacing average electricity generation given in Table 4 is consistent with an attributional LCA approach. The other assumption, that electricity generated from the waste-to-energy technologies displaces coal based condensing power, is consistent with a consequential LCA approach with a short term marginal perspective where only existing generation capacities are considered. As such, according to (Danish Energy Agency 2011), the short term marginal power plant is typically a condensing power plant fully or partly fired with coal. Biogas CHP plants can be regulated to match demand variations within the day, while waste incineration plants are restricted to be operated as base load, for emission control reasons (Danish Energy Agency \& Energinet.dk 2012). From this perspective, we could argue that biogas CHP is more likely to displace dispatchable flexible power plants such as coal (or natural gas) fired units, while waste incineration CHP is more likely to displace a mix of different types of electricity generation as illustrated in the W-Av, B-Coal scenario in Table 4.

Table 4. Scenarios for electricity generation displaced by waste incineration CHP and biogas CHP.

\begin{tabular}{lll}
\hline Name & Waste incineration $C H P$ & Biogas $C H P$ \\
\hline W-Av, B-Coal & Average Danish electricity & Coal based electricity, condensing \\
\hline
\end{tabular}




\begin{tabular}{lll}
\hline W-Av, B-Av & Average Danish electricity & Average Danish electricity \\
\hline W-Coal, B-Coal & Coal based electricity, condensing & Coal based electricity, condensing \\
\hline
\end{tabular}

Source: (Danish Energy Agency 2011)

\subsection{Results}

In the following, results are illustrated for the scenario W-Av, B-Coal, described in Table 4. The greenhouse gas (GHG) emissions for the three different alternatives are illustrated in Figure 5 distributed on sources.

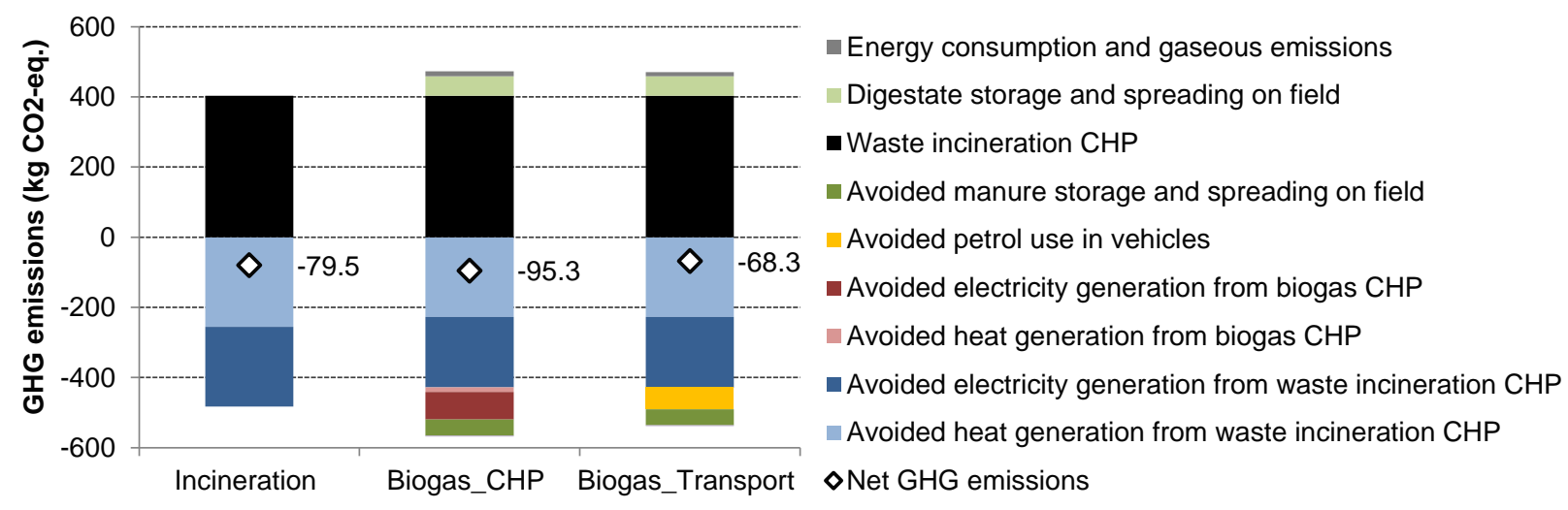

Figure 5. Induced, avoided and net greenhouse gas emissions for three different treatments of 1 tonne residual household waste (Incineration, Biogas_CHP, and Biogas_Transport). Results are shown for the electricity generation displacement scenario W-Av, B-Coal, described in Table 4.

As shown in Figure 5, the Biogas_CHP alternative provides the largest GHG emission reduction. Furthermore, all three alternatives generate GHG emissions from the waste incineration of the fossil content in the residual household waste (mainly plastics). However, the electricity and heat generated from the waste incineration results in somewhat larger avoided GHG emission. In the Biogas_CHP and Biogas_Transport alternatives, the GHG reduction from the avoided heat generation is moderately lower since less heat is produced. On the other hand, in the Biogas_CHP alternative, a large GHG emission reduction is obtained from avoided electricity generation through biogas CHP. In the Biogas_Transport alternative, the GHG emission reduction provided by avoided petrol use in vehicles is lower compared to the reduction obtained when using biogas for CHP generation.

The operation costs for the three different alternatives are illustrated in Figure 6 distributed on sources. 


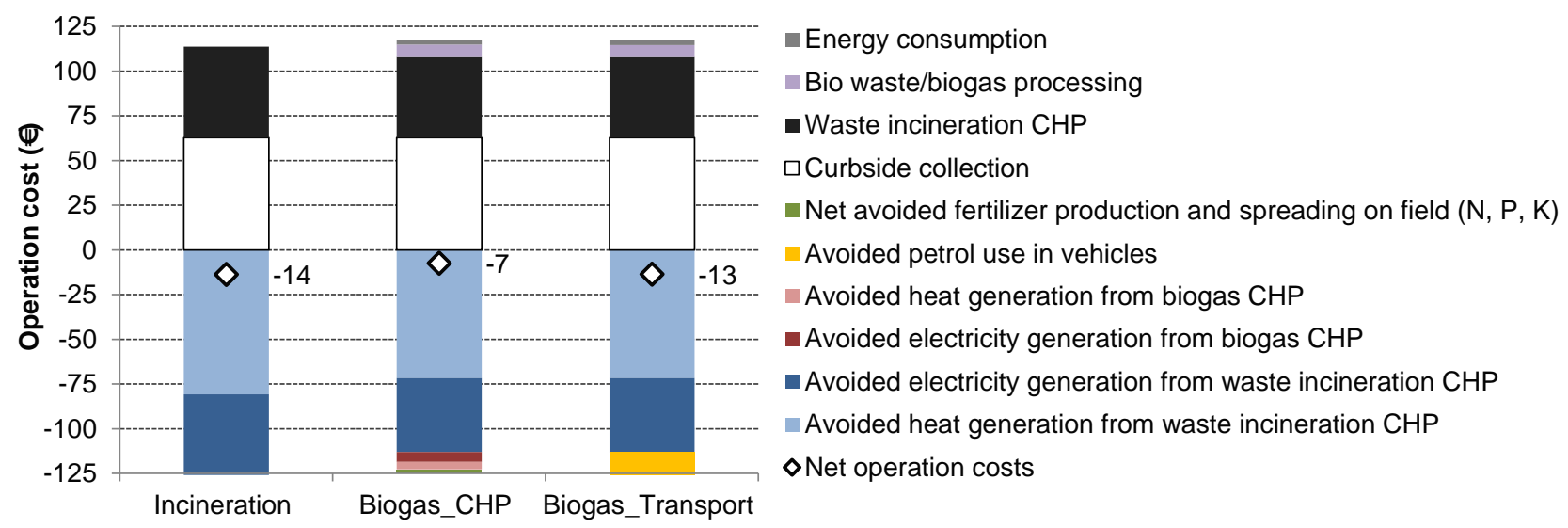

Figure 6. Costs and benefits for three different treatments of 1 tonne residual household waste (Incineration, Biogas_CHP, and Biogas_Transport). Results are shown for the electricity displacement scenario W-Av, B-Coal, described in Table 4.

It can be seen that curb side collection and waste incineration comprise the major operational costs for all three alternatives. The avoided electricity and heat generation from waste incineration constitute the largest benefits. The use of biogas as fuel in vehicles provides larger benefit than the use as fuel in CHP generation. The lowest variable operation costs are found in the Incineration alternative. If used to support an investment decision, investment costs would have to be added. Here biogas plants are more expensive per tonne input (12.5 k€/t incl. CHP and $11.9 \mathrm{k} € / \mathrm{t}$ excl.) than incineration plants $(5.8 \mathrm{k} € / \mathrm{t}$ incl. CHP) (Danish Energy Agency \& Energinet.dk 2012). Investing in upgrading and compressing biogas for use in transport is more costly than investing in a CHP unit (costs are around $2 \mathrm{k} € / \mathrm{Nm} 3 \mathrm{raw}$ gas ), but on the other hand facilitates a bigger market for the output (Evald et al. 2013).

This issue is an interesting topic for future research with focus on long term marginals.

As a result of the above, the model selects the Biogas_CHP alternative, when minimizing GHG emissions and the Incineration alternative, when minimizing operational costs. The identified optimal waste treatments are presented in Table 5 for different objectives and the electricity generation assumed displaced by the waste-to-energy technologies.

Table 5. Optimal treatment of residual household waste depending on the objective and the electricity generation assumed displaced by waste incineration CHP and biogas CHP.

Objective

\begin{tabular}{llll} 
& & Min. GHG emissions & Min. operation costs \\
\hline $\begin{array}{l}\text { Electricity } \\
\text { generation }\end{array}$ & $\mathrm{W}-\mathrm{Av}, \mathrm{B}-\mathrm{Coal}$ & Biogas_CHP & Incineration \\
\cline { 2 - 4 } $\begin{array}{l}\text { assumed } \\
\text { displaced* }\end{array}$ & $\mathrm{W}-\mathrm{Av}, \mathrm{B}-\mathrm{Av}$ & Incineration & Incineration \\
\cline { 2 - 4 } & $\mathrm{W}-\mathrm{Coal}, \mathrm{B}-\mathrm{Coal}$ & Incineration & Biogas_Transport
\end{tabular}

*The different types of electricity generation assumed displaced are described in Table 4.

Table 5 shows that the optimal waste treatment alternative is Incineration, Biogas_CHP, or Biogas_Transport, depending on whether the optimization objective is to minimize GHG emissions or operation costs and depending on the type of electricity generation which is assumed to be displaced. 
Similar differences can be expected with different assumptions regarding displaced heat production.

The case study illustrated here is very simple as an optimization problem. Indeed, there is only one Process that represents a choice possibility, viz., the Process that splits the initial residual household waste between the three treatment possibilities. Here there are inequalities representing that the share of any one of the three treatment possibilities is non-negative; additionally they must add up to $100 \%$. This is the only place where inequalities are present. An optimal solution therefore has the property that all waste will be sent to one of the three treatment possibilities, depending on the optimization criterion and input parameters as illustrated. The fact that the presentation could also be seen as close to a traditional LCA with three treatment possibilities emphasises the appropriateness of the model in the LCA perspective while at the same time it illustrates the potential for extensions towards integration of LCA and ESA analyses.

\section{CONCLUSIONS}

We have presented a first version of the linear optimisation model OptiWaste. In the model, the choice of optimal waste handling options is made endogenously, i.e. as a result of the optimisation. In comparison, when using LCA to analyse different waste handling solutions, a number of user defined alternatives are compared in what-if analyses, where the best solutions are identified in the interpretation of the results.

The model is flexible in that the number of process steps and flows and the composition of waste handling paths can be defined freely by the user. Moreover, the model makes it possible to perform optimisation with different objectives, e.g. minimizing GHG emissions or costs, as illustrated in this case study; or by optimizing with regard to several objectives given different weights.

As shown in the illustrative case study, assumptions regarding the affected electricity generation can significantly influence the optimal solution. Furthermore, what is optimal from an environmental perspective may not be optimal from an economic perspective. In the present model, the type of electricity and heat generation displaced by waste-to-energy technologies are given exogenously as input data. Ideally, the affected energy generation should be identified as part of the optimisation in a model covering the waste management sector in integration with the energy system. This will be subject for future work in which a temporal and geographical dimension will be implemented as well as capacity limitations, storages, electricity trade between regions, and variations in demand and renewable energy production. Furthermore, a long term marginal perspective could be incorporated, facilitating optimization of investments.

In the illustrative case study, the optimisation results in choosing either one or the other waste treatment alternative. This is a consequence of the model set up at this point. In the future model capturing the dynamics described above, the optimal treatment paths identified by the model can constitute combinations of different options, as in reality.

The work presented in this article is believed to be a significant step forward in developing a modelling tool which enables an integrated analysis of the sectors of both waste management and energy, taking into account both economy and environment.

\section{ACKNOWLEDGEMENTS}

The authors would like to thank Ciprian Cimpan and Ole L. Dall, University of Southern Denmark, as well as Anna Bernstad, Lund University, for contributing in providing data for the case study. Thanks are also given to the TOPWASTE project group for valuable feedback along the way and to the Danish Strategic Research Council for funding the work. 


\section{REFERENCES}

Astrup, T. F., Tonini, D., Turconi, R., \& Boldrin, A. 2014, Life cycle assessment of thermal Waste-toEnergy technologies: Review and recommendations. Waste Management, in press.

Bazaraa, M. S., Jarvis, J. J., \& Sherali, H. D. 2010, Linear Programming and Network Flows John Wiley \& Sons.

Bernstad, A. Household food waste management - Evaluations of current status and potential improvements using life-cycle assessment methodology. PhD thesis. Lund University, 2012

Bernstad, A., \& la Cour Jansen, J. 2012, Review of comparative LCAs of food waste management systems-Current status and potential improvements. Waste management, vol. 32, no. 12, pp. 24392455.

Beurskens, L. W. M. \& Hekkenberg, M. 2011, Renewable Energy Projections as Published in the National Renewable Energy Action Plans of the European Member States - Covering all 27 EU Member States ECN-E--10-069. The Energy research Centre of the Netherlands (ECN) and the European Environment Agency (EEA).

Broitman, D., Ayalon, O. \& Kan, I. 2012, One size fits all? An assessment tool for solid waste management at local and national levels, Waste Management, vol. 32, pp. 1979-1988

Dall, O. University of Southern Denmark, Personal communication, June 2013

Danish Energy Agency 2011, Guidelines in socio-economic analysis in the field of energy. Danish Energy Authority, Copenhagen

Danish Energy Agency 2012, Energy statistics 2011 (in Danish). Ministry of Climate and Energy, Copenhagen, Denmark

Danish Energy Agency \& Energinet.dk 2012, Technology Data for Energy Plants - Generation of Electricity and District Heating, Energy Storage and Energy Carrier Generation and Conversion. Danish Energy Agency, Copenhagen, Denmark

Danish Ministry of Climate Energy and Building, 2012, DK Energy Agreement, https://stateofgreen.com/files/energyagreement, March 222012.

Dijkgraaf, E. \& Vollebergh, H. R. J. 2004, Burn or bury? A social cost comparison of final waste disposal methods, Ecological Economics, vol. 50, no. 3-4, pp. 233-247.

Dornburg, V. \& Faaij, A. P. C. 2006, Optimising waste treatment systems: Part B: Analyses and scenarios for The Netherlands, Resources, Conservation and Recycling, vol. 48, no. 3, pp. 227-248.

Edwards, R., Larivé, J. F., \& Beziat, J. C. 2011, Well-to-wheels Analysis of Future Automotive Fuels and Powertrains in the European Context - Tank-to-Wheels Report Version 3c. European Commission Joint Research Centre, Institute for Energy, 
El Hanandeh, A. \& El-Zein, A. 2009, Strategies for the municipal waste management system to take advantage of carbon trading under competing policies: The role of energy from waste in Sydney, Waste Management, vol. 29, no. 7, pp. 2188-2194.

Eshet, T., Ayalon, O., \& Shechter, M. 2005, A critical review of economic valuation studies of externalities from incineration and landfilling, Waste Management \& Research, vol. 23, no. 6, pp. 487504.

European Parliament \& Council. Directive 2008/98/EC of the European Parliament and of the Council of 19 November 2008 on waste and repealing certain Directives (Text with EEA relevance). 19-112008.

Evald, A., Hu, G., \& Hansen, M. T. 2013, Technology data for advanced bioenergy fuels 112-33699. FORCE Technology, Department for Biomass \& Waste, Kgs. Lyngby, Denmark

Finnveden, G., Bjorklund, A., Reich, M. C., Eriksson, O., \& Sorbom, A. 2007, Flexible and robust strategies for waste management in Sweden, Waste Management, vol. 27, no. 8, p. S1-S8.

Finnveden, G., Bjorklund, A., Ekvall, T., \& Moberg, A. 2006, Models For Waste Management: Possibilities And Limitations, in ISWA 2006 "Waste Site Stories", ISWA.

Hamelin, L. 2013, Carbon management and environmental consequences of agricultural biomass in an Danish renewable energy strategy.

Juul, N., Münster, M., Ravn, H., \& Ljunggren Söderman, M. 2013, Challenges when performing economic optimization of waste treatment. Waste Management, vol. 33, no9, pp. 1918-1925.

Kan, I., Ayalon, O. \& Federman, R. 2010, On the efficiency of composting organic wastes, Agricultural Economics, vol. 41, pp. 151-163

Laurent, A., Bakas, I., Clavreul, J., Bernstad, A., Niero, M., Gentil, E., Hauschild, M. \& Christensen, T. H. 2014, Review of LCA studies of solid waste management systems-Part I: Lessons learned and perspectives. Waste management, vol. 34, no. 3, pp. 573-588.

Ljunggren Söderman, M. 2000, Modelling national solid waste management, Waste Management \& Research, vol. 18, no. 6, pp. 525-537.

Longden, D., Brammer, J., Bastin, L., \& Cooper, N. 2007, Distributed or centralised energy-fromwaste policy? Implications of technology and scale at municipal level, Energy Policy, vol. 35, no. 4, pp. 2622-2634.

Luoranen, M. \& Horttanainen, M. 2007, Feasibility of energy recovery from municipal solid waste in an integrated municipal energy supply and waste management system, Waste Management \& Research, vol. 25, no. 5, pp. 426-439.

Morris, J., Scott Matthews, H., \& Morawski, C. 2013, Review and meta-analysis of 82 studies on endof-life management methods for source separated organics. Waste management, vol. 33, no. 3, pp. 545551. 
Morrissey, A. J. \& Browne, J. 2004, Waste management models and their application to sustainable waste management, Waste Management, vol. 24, no. 3, pp. 297-308.

Moutavtchi, V., Stenis, J., Hogland, W., Shepeleva, A., \& Andersson, H. 2008, Application of the WAMED model to landfilling, Journal of Material Cycles and Waste Management, vol. 10, no. 1, pp. 62-70.

Münster, M. \& Meibom, P. 2010, Long-term affected energy production of waste to energy technologies identified by use of energy system analysis, Waste Management, vol. 30, no. 12, pp. 2510-2519.

Münster, M. 2009, Energy System Analysis of Waste to Energy Technologies, PhD thesis, Aalborg University.

Münster, M. \& Meibom, P. 2011, Optimization of use of waste in the future energy system, Energy, vol. 36, no. 3, pp. 1612-1622.

Murphy, J. D. \& McKeogh, E. 2004, Technical, economic and environmental analysis of energy production from municipal solid waste, Renewable Energy, vol. 29, no. 7, pp. 1043-1057.

Nielsen, L. H., Hjort-Gregersen, K., Thygesen, P., \& Christensen, J. Socio-economic Analysis of Centralised Biogas Plants - with technical and corporate economic analysis (In Danish). 2002. Report no. 136. Institute of Food and Resource Economics, Copenhagen

Petersen, C. and I. Domela (2003). Sammensætning af dagrenovation og ordninger for hjemmekompostering [Composition of municipal waste and home composting schemes (in Danish)]. Miljøprojekt No. 868. Environmental Protection Agency, Copenhagen, Denmark,

Ravn, H., Hindsberger, M., Petersen, M., Schmidt, R., Bøg, R., Grohnheit P.E., et al. 2001, Balmorel: A Model for Analyses of the Electricity and CHP Markets in the Baltic Sea Region. ElkraftSystem, Denmark

Shmelev, S. E. \& Powell, J. R. 2006, Ecological-economic modelling for strategic regional waste management systems, Ecological Economics, vol. 59, no. 1, pp. 115-130.

Sundberg, J., Olofsson, M., \& Sahlin, J. 2004, Evaluating waste incineration as treatment and energy recovery method from an environmental point of view. Profu, Mölndal, Sweden

Tietze-Stockinger, I., Fichtner, W., \& Rentz, O. 2004, A model to minimize joint total costs for industrial waste producers and waste management companies, Waste Management \& Research, vol. 22, no. 6, pp. 466-476.

Villanueva, A. \& Wenzel, H. 2007, Paper waste - Recycling, incineration or landfilling? A review of existing life cycle assessments, Waste Management, vol. 27, no. 8, p. S29-S46.

Winkler, J. \& Bilitewski, B. 2007, Comparative evaluation of life cycle assessment models for solid waste management, Waste Management, vol. 27, no. 8, pp. 1021-1031. 